\title{
Rethinking the origins of the British Prisons Act of 1835: Ireland and the development of central-government prison inspection, 1820-35
}

\begin{abstract}
While the introduction of central-government inspectors of prisons in the British Prisons Act of 1835 has been seen as a key Whig achievement of the 1830s, alongside the new factory and poorlaw inspectorates, the Irish precedent set by liberal Tory reforms in the early 1820s has gone unnoticed by scholars. The essay sets out to trace the Irish origins of this reforming measure and in the process to establish prison reform in the United Kingdom as more of a transnational issue. A new analysis of the critical years of 1823-35 in both Britain and Ireland based on a detailed examination of parliamentary inquiries and legislation will show how developments in the two countries overlapped and of how Irish reforms affected British policy. The effects of these reforms will be analysed in both mainland Britain and Ireland, but also in its later impact in Europe and the British imperial world. By highlighting the achievements of Tory policy in Ireland in the 1820 s, and by stressing the continuities between British administrations of the 1820s and 1830s, this article will pose the broader question of whether certain Whig achievements of the reform years were really as revolutionary as some current scholarship would suggest.
\end{abstract}

'I think nothing ... is so likely to do good as government inspectors [whom] I consider as officers of the great importance,' declared the penal reformer Elizabeth Fry before a House of Lords inquiry in 1835, as 'Government Inspectors [that] I consider as Officers of the greatest Importance'. 'They do great good in Ireland,' she insisted, and 'they would do much good in 
England. ${ }^{11}$ The introduction of central-government inspectors of prisons in Britain has been seen as a key Whig achievement of the 1830s, alongside the new factory and poor-law inspectorates. But the Irish precedent set by liberal Tory reforms in the early 1820 s has gone unnoticed by scholars, and British prison reform has mistakenly been seen primarily within the context of English politics. The essay sets out to trace the Irish origins of the most important legislative reform of the time, the British Prisons Act of 1835, and in the process to establish prison reform in the United Kingdom as more of a transnational issue. Parts 1 and 2 of the essay will analyse, respectively, Irish and British penal reform policy from the late eighteenth century to about 1823. Part 3 will look at the crucial years 1823-35 in both countries and offer a new analysis, based on detailed examination of parliamentary inquiries and new legislation, of how developments in the two countries overlapped and of how Irish reforms affected British policy. Part 4 will look briefly at prison reform in Britain after 1835, and examine how the Anglo-Irish issue of centralgovernment inspection spread to other parts of Europe and to the British imperial world. By highlighting the achievements of liberal Tory policy in Ireland in the 1820s, and by stressing the continuities between the British administrations of the 1820s and 1830s, this article will pose a broader question - whether certain of the Whig 'achievements' of the reform years were really as revolutionary as some current scholarship would suggest.

In the early evolution of the nineteenth-century British prison system, legislation from two years looms large: 1823 and $1835 .^{2}$ The first act-Peel's measure to set up a local inspection system managed by Justices of the Peace and to introduce classification of prisoners by gender and type of offence — was at its heart prompted by practicalities and not by a desire to bring about sweeping or extensive changes. It called for tangible, and often architectural, changes to existing prisons, but its ambition, scope, and effect were limited. The second law- the Whig

\footnotetext{
1 Second Report from the Select Committee of the House of Lords Appointed to Inquire into the Present State of the Several Gaols and Houses of Correction in England and Wales, H.L. 1835 (439), xi, p. 341.

2 Ursula R.Q. Henriques, Before the Welfare State: Social Administration in Early Industrial Britain (London, 1979), pp. 155-78.
} 
government's introduction of a centrally-funded prison inspectorate in 1835-represented instead a change in the philosophy of administration and reflected a shift in the principles then governing penal reform. By its unavoidable encroachment on the powers of local government, then for the most part controlled by Justices of the Peace, this second act constituted a key episode in the emergence of nineteenth-century central-government planning and bureaucracy; it led within a few decades to complete central control of all British prisons. ${ }^{3}$ As Robert Cooper has argued, the issue of inspection was quite distinct and unique; it was little influenced by, for example, the evangelicalism of Elizabeth Fry or the utilitarianism of the Benthamites, in that it concerned the issue of enforcement. There was little point in making laws about how prisoners should be housed or treated if central government had no powers of enforcement over the local elites who managed these prisons. ${ }^{4}$ Inspection, which could expose failings, produce uniformity of standards, and drive up quality, was an essential new weapon of government at the time. ${ }^{5}$ The existing historiography highlights the natural resistance of local magistrates to the cession of power to central government and underscores the reluctance of the Tory party to challenge these local authorities in their management of prisons in any meaningful manner. ${ }^{6}$ As Norman Gash has argued, imposing central-government inspectors would have been 'scarcely practicable' during Peel's time as Home Secretary. Few Tory voices saw the benefit in usurping the historic right of local elites to manage their own criminal-justice systems. Characteristically, Peel opted instead for 'modest and pragmatic alterations,' according to Randall McGowen, leaving more

\footnotetext{
${ }^{3}$ Sidney and Beatrice Webb, English Prisons under Local Government (London, 1922), p. 112.

${ }^{4}$ Robert Alan Cooper, 'Jeremy Bentham, Elizabeth Fry, and English Prison Reform,' Journal of the History of Ideas 42:4 (Oct.-Dec. 1981), pp. 675-90, pp. 686-87.

${ }^{5}$ Henriques, Before the Welfare State, pp. 250-52. Oliver MacDonagh, The Inspector General, Sir Jeremiah Fitipatrick and the Politics of Social Reform, 1783-1802 (London, 1981), pp. 320-26; Stephen Shute, 'On the Outside Looking In: Reflections on the Role of Inspection in Driving Up Quality in the Criminal Justice System,' The Modern Law Review 76:3 (May 2013), pp. 494-528.

${ }^{6}$ Webb, English Prisons under Local Government, pp. 75, 109-12. Sean McConville, A History of English Prison Administration. Volume I: 1750-1877 (London, 1981), p. 170. Randall McGowen, ${ }^{\top}$ The Well-Ordered Prison: England 1780-1865,' in Morris and Rothman (eds.), Oxford History of the Prison, pp. 79-110, esp. p. 89.
} 
radical measures for a more radical decade. ${ }^{7}$ It was only under the Whig governments of the 1830s that a fundamental shift in British penal policy occurred, and this change precipitated the introduction of inspectors in the 1835 act. $^{8}$

This narrative has remained unchallenged for nearly a century, owing largely to the extent to which the debate has been dominated by the convincing and elegant prose of the first major classic on the subject-Sidney and Beatrice Webb's English Prisons under Local Government (1922). Though Robert Alan Cooper has criticized the 'often distorted and inaccurate' nature of the Webbs' pioneering study, the influence of their political standpoint—as celebrated left-wing intellectuals—has not been scrutinized. ${ }^{9}$ The Webbs' interest in the growth of the power of central government, seen through the prism of the development of the Welfare State, has coloured subsequent histories of prison reform. Coupled with their particular perspective has been the disproportionate interest of left-leaning historians in penal issues more broadly. The establishment of central-government prison inspectors has been understood in the current literature as a Whig achievement; it has been explained with reference to the precedents set by the Factory Act of 1833 and the New Poor Law of 1834, both of which called for government inspectors, and were introduced by the Whigs. These precedents, it has been argued, legitimized the extension of the new system of enforcement-by-inspection to the poorly-organized and unaccountable prison system. ${ }^{10}$ Within this framework there has not been sufficient analysis of

\footnotetext{
${ }^{7}$ Norman Gash, Mr. Secretary Peel: The Life of Sir Robert Peel to 1830 (London and New York, 1985), pp. 315-17; McGowen, 'The Well-Ordered Prison,' p. 89.

${ }^{8}$ Webb, English Prisons under Local Government, pp. 110-12; Margaret Heather Tomlinson, 'Victorian Prisons: Administration and Architecture, 1835-1877' (Ph.D. Thesis, Bedford College, University of London, 1975), p. 53; McConville, English Prison Administration, p. 170; Patrick Carroll-Burke, Colonial Discipline: the Making of the Irish Convict System (Dublin, 2000), p. 50; Douglas Hurd, Robert Peel: A Biography (London, 2007), p. 79.

${ }^{9}$ Robert Alan Cooper, 'Ideas and Their Execution: English Prison Reform,' Eighteenth-Century Studies 10:1 (Autumn, 1976), pp. 73-93, esp. p. 73.

${ }^{10}$ Factory inspectors were appointed following the 1833 Factories Act (3 \& 4 Will. IV. c. 103). Assistant poor-law commissioners (later known simply as inspectors) were established after the 1834 Poor Law Amendment Act, otherwise known as the New Poor Law of 1834 (4 \& 5 Will. IV. c. 76). See Ursula R.Q. Henriques, 'An Early Factory Inspector: James Stuart of Dunearn,' The Scottish Historical Review, 50, no.
} 
Tory policy in the same years, and in particular Tory policy in Ireland. The existing narrative is ripe for re-examination, not least because there are remarkably few references to either the factory or poor-law inspectors in the many select-committee reports and parliamentary debates concerned with penal-reform issues in the twenty years leading to the seminal 1835 act. British penal reform also needs to be considered in a more transnational manner, especially one that takes into account the effect that penal-reform policy in Ireland exerted on contemporary debates in Britain.

I argue that the prototype for central-government prison inspection was neither the factory nor the poor-law inspectorates but rather the system developed in Ireland for managing prisons in the early 1820s, pioneered by two Tory chief secretaries: Charles Grant and Henry Goulburn. ${ }^{11}$ Existing accounts have failed to fully recognize the importance of the fact that whenever inspection was discussed in the 1820 s and 1830s, it was with explicit reference to the Irish system. Contemporary voices saw Ireland as the obvious testing-ground for their plans. A central-government inspectorate had been in place there ever since 1786 and had gained significant new powers and influence through a reforming measure of $1822 .{ }^{12}$ Once the origins of the key British act of 1835 have been more fully explained, this essay will re-examine the extent to which the introduction of inspectors can be claimed as an achievement of the Whig governments of the 1830s, as opposed having been a nature extension of liberal Tory opinion in the preceding decade.

149, part 1 (April 1971), pp. 18-46; Peter Mandler, Aristocratic Government in the Age of Reform: Whigs and Liberals, 1830-1852 (Oxford, 1990), pp. 135-37, 148-50.

${ }^{11}$ Ged Martin, 'Charles Grant,' in H.C.G. Matthew and Brian Harrison (eds.), Oxford Dictionary of National Biography (Oxford, 2004), 54: pp. 293-96, esp. p. 293. Daniel Beaumont, 'Charles Grant,' in James McGuire and James Quinn (eds.), Dictionary of Irish Biography (Cambridge, 2009), 4: pp. 195-97, esp. p. 196. David Eastwood, 'Henry Goulburn,' in Matthew and Harrison, Oxford Dictionary of National Biography, 54: pp. 62-66, esp. p. 64.

${ }_{12}$ Fourth and Fifth Reports from the Select Committee of the House of Lords Appointed to Inquire into the Present State of the Several Gaols and Houses of Correction in England and Wales, H.L. 1835 (441), xii, pp. 684-85. 
Historians of British penal reform have, with very few exceptions, neglected to consider whether policies in Ireland may have informed or influenced contemporary British political opinion. Both the Webbs and R.S.E. Hinde's The British Penal System (1951) make only fleeting references to Ireland, limited to the period after 1840, when the tide had turned and Irish policy was being derived from English and Scottish examples. Sir Llewellyn Woodward's Age of Reform, 1815-1870, provides gives a history of British penal reform without any reference to Ireland, and this imbalance is replicated in later works by Ursula Henriques and Robert Alan Cooper. The most comprehensive accounts of prison inspection—by Eric Stockdale and Stephen Shutesimply acknowledge the existence of a separate and earlier Irish system but do not pursue the matter any further. ${ }^{13}$ Perhaps more surprising is the omission of this topic from Norman Gash's account of Peel's time as both Irish Chief Secretary and later Home Secretary. ${ }^{14}$ More recent surveys have continued this trend: The Oxford History of the Prison (1995) does not mention Ireland at all in the index, nor are there mentions of Ireland in Richard Follett's account of criminal-law reform in England in the early nineteenth century (2001) or in James Willis's analysis of British penal reform (2005). ${ }^{15}$ Where penal reform has been seen as more than a purely domestic issue, reference has been made to the wider Atlantic world - to Pennsylvania in particular, and sometimes to France-but not to Ireland. Yet the fog hanging over the Irish Sea has also hampered the (admittedly) far fewer accounts by Irish historians of specifically Irish penal history; in the works of R.B. McDowell, Oliver MacDonagh, and others, not enough space has

\footnotetext{
${ }_{13}$ Webb, English Prisons under Local Government, pp. 182, 200; R.S.E. Hinde, The British Penal System. 1773 1950 (London, 1951), pp. 117-18; Ernest Llewellyn Woodward, The Age of Reform, 1815-1870 (2nd ed., Oxford, 1962); Ursula R.Q. Henriques, 'The Rise and Decline of the Separate System of Prison Discipline,' Past \& Present 54 (Feb. 1972), pp. 61-93. Tomlinson; 'Victorian Prisons,' p. 50; Eric Stockdale, 'A Short History of Prison Inspection in England,' British Journal of Criminology 23:3 (1983), pp. 213-16; Stephen Shute, 'On the Outside Looking In'.

${ }^{14}$ Gash, Mr. Secretary Peel, pp. 315-17.

${ }^{15}$ Norval Morris and David J. Rothman (eds.), The Oxford History of the Prison: The Practice of Punishment in Western Society (Oxford, 1995); Richard R. Follett, Evangelicalism, Penal Theory, and the Politics of Criminal Law Reform in England, 1808-30 (Basingstoke, 2001); James J. Willis, 'Transportation versus Imprisonment in Eighteenth- and Nineteenth-Century Britain: Penal Power, Liberty, and the State,' Law \& Society Review 39:1 (March 2005), pp. 171-210; Stephen Shute, 'On the Outside Looking In'.
} 
been given to discussing British, continental or American influences. ${ }^{16}$ The problem of assessing transnational influence on prison-inspection policy has clearly operated in both directions and therefore offers ample opportunity for revision and reinterpretation.

The connections in this field between Ireland and Britain were both numerous and influential. After the Act of Union all prison legislation passed through the same houses of parliament and through select committees often populated by the same few parliamentarians who were interested in the state of the prisons. For example, George Holford, spent much time in Ireland (his wife's native country) and took a leading role in both British and Irish prison reform, publishing in 1821 his Thoughts on the Criminal Prisons of This Country: Occasioned by the Bill Now in the House of Commons. ${ }^{17}$ This bill to reform the management of England's prisons, which eventually became law in 1823, included a provision on dietary regimes that Holford, demonstrating his knowledge of Irish affairs, rightly claimed was 'taken with little variation' from an Irish act of $1810 .{ }^{18}$ Similarly, with respect to prison fees, which prisoners had to pay to gaolers until the fees were abolished in Britain in 1815, an Irish act of 1821 simply copied and reused the existing clauses of the British measure. ${ }^{19}$ From the late 1810 s too, the Irish Society for the Improvement of Prisons and Prison Discipline (SIPPD) maintained regular communication with its more established British near-namesake (SIPD), exchanging ideas about prison plans, regimes, inspection, and legislation. ${ }^{20}$ Further examples of cross-channel influences can be found when.

\footnotetext{
16 R.B. McDowell, The Irish Administration, $1801-1914$ (London, 1964), pp. 145-63. Oliver MacDonagh, 'Ideas and Institutions, 1830-45,' pp. 211-12. R.B. McDowell, 'Administration and the Public Services, 1800-70,' pp. 538-61, in W.E. Vaughan (ed.), A New History of Ireland. Volume V: Ireland under the Union, Part 1: $1801-70$ (Oxford, 1989), pp. 545-46.

${ }^{17}$ George Holford, Thoughts on the Criminal Prisons of This Country: Occasioned by the Bill Now in the House of Commons for the Consolidating and Amending the Laws Relating to Prisons (London, 1821). See Journal of the House of Commons 76 (1821), pp. 117ff; R.G. Thorne, 'George Peter Holford,' in R.G. Thorne (ed.), The History of Parliament: The House of Commons 1790-1820 (London, 1986) 4: pp. 214-16.

${ }^{18}$ Holford, Thoughts on the Criminal Prisons, pp. 16-17. Prisons (Ireland) Act, 1810 (50 Geo. III. c. 103).

${ }^{19}$ Gaol Fees Abolition Act, 1815 (55 Geo. III. c. 50). Abolition of Gaol Fees (Ireland) Act, 1821 (1 \& 2 Geo. IV. c. 77).

${ }^{20}$ The British society was founded in 1808, the Dublin society in December 1818. See An Account of the Origin and Object of the Society for the Diffusion of Knowledge upon the Punishment of Death, and the Improvement of
} 
For instance, when calling for reforms to Scottish prisons in the 1820 s, the Inverness gentry supported the adoption of recently-established Irish inspection measures, and when a Brighton magistrate was asked for his views on the British prison act in 1835 , he drew attention to the work of the Irish prison inspectors, saying that he had in his possession 'all the reports of the prisons in Ireland'. ${ }^{21}$

\section{I}

Ireland became the first country in the world to appoint a government-salaried prison inspector in 1786. Sir Jeremiah Fitzpatrick (ca. 1740-1810) earned the nickname of 'the second Howard' after the prominent British reformer John Howard. Like Howard, Fitzpatrick saw that many new prisons were being built throughout Ireland, and he published An Essay on Gaol-Abuses in 1784 and Thoughts on Penitentiaries in 1790. Though he brought great passion and commitment to improving the condition of Irish prisons, his achievement should not be overstated, and he left the position in 1793 when offered an inspectorate in the army. ${ }^{22}$ By tendering timely and judicious advice and by publicly denouncing abuses needing correction, Fitzpatrick helped to make Irish prisons marginally less like the primitive and abysmal dungeons that they had been up to this point. One of the issues hampering further reform was the three-year gap in 1793-96 between Fitzpatrick's departure and the appointment of his successor, the Rev. Forster Archer, a Church of Ireland minister from Cork. Archer held his position for over twenty-five years, but he has been described by one modern historian as a 'commonplace, untrained and unenthusiastic functionary, apparently appointed for political convenience and without any prior knowledge of

Prison Discipline (London, 1812); First Report of the Association for the Improvement of Prisons and of Prison Discipline in Ireland for 1819 (Dublin, 1820), p. 11.

${ }^{21}$ Report from the Select Committee on the State of Prisons in Scotland, H.C. 1826 (381), v, p. 81; First Report from the Select Committee of the House of Lords Appointed to Inquire into the Present State of the Several Gaols and Houses of Correction in England and Wales, H.L. 1835 (438), xi, p. 177.

2226 Geo. III. c. 27, ss. $4-7$ (1786), and 27 Geo. III. c. 39, s. 6 (1787). MacDonagh, Inspector General.

McDowell, Irish Administration, pp. 150-51. 
or interest in the gaols. ${ }^{23}$ Some new prisons in county towns, however, were built during his tenure, including those in Galway, Tralee and Cork. ${ }^{24}$ With his retirement in 1821 came a watershed moment in the history of Irish prison inspection, brought about in no small part by Archer's woeful performance at a Tory-instituted House of Commons inquiry in 1819 into the state of the United Kingdom's prisons-the first truly comprehensive investigation since the Act of Union. By this time, thanks in part to the work of the SIPD societies in Dublin and London, increased focus was being placed on the smaller prisons (known in Ireland as bridewells) that dotted the provincial market towns. ${ }^{25}$

The chairman of the inquiry, Charles Bathurst, thoroughly interrogated Archer, highlighting his lack of attention to these bridewells. Over the course of five days in May, Archer was subjected to a barrage of hostile questions, more than any other witness except an Australian on the transportation of convicts. ${ }^{26}$ Archer was asked if his report on Irish prisons was based on visits to them all, or just to some of them, and when he had last visited a dozen or so named prisons. He had to admit that most bridewells were not built in accordance with legal requirements. ${ }^{27}$ His answers cannot have instilled much confidence in his office or in the efficacy of central-government inspection. Whatever Archer's qualifications may have been for the post in the 1790s, organisations such as the SIPD and SIPPD were now exerting more influence in both London and Dublin, and expectations had markedly increased. In this new environment Archer's informal manner was deemed unsatisfactory, and the nature of the questioning suggests

\footnotetext{
${ }^{23}$ MacDonagh, Inspector General, p. 143. See also Forster Archer to Charles Grant, 19 Dec. 1821 (Chief Secretary's Office Registered Papers, 1822-3212 (hereafter cited as CSORP), National Archives of Ireland, Dublin (hereafter cited as NAI); Correspondence on the Subject of Granting a Superannuation Allowance to the Revd. Foster Archer, Late Inspector General of Prisons in Ireland, H.C. 1823 (264), xvi. Archer agreed to be an alias for the government in prosecuting a libel case against the editor of the radical Cork Gazette newspaper in 1794. See Brian Inglis, The Freedom of the Press in Ireland. 1784-1841 (London, 1954), pp. 88-89.

${ }^{24}$ Galway (1810), Tralee (1812) and Cork city (1824). See McDowell, Irish Administration, pp. 151-53.

${ }^{25}$ Report from the Select Committee on the State of Gaols, etc., H.C. 1819 (579), vii, pp. 191-93, 195, 243.

${ }^{26}$ Ibid., pp. 9-148, 195-235.

${ }^{27}$ Ibid., pp. 195, 201, 204. The legislation in force was the Prisons (Ireland) Act of 1810 (50 Geo. III. c. 103), amended in 1815 (55 Geo. III. c. 92), which had introduced classification by gender and offered central-government financial assistance to replace old prisons.
} 
that members of the Irish administration may have used the opportunity to advance alreadyfermenting plans to have him replaced with a more diligent and committed inspector versed in the new SIPD rhetoric of administrative efficiency and humanitarian concern. ${ }^{28}$ The appointment of a new Irish Chief Secretary, Charles Grant, added further impetus for change. He became the official patron of the Irish SIPPD immediately upon its establishment in 1818 and remained in this role long after he had departed Ireland in $1822 .{ }^{29}$ Though the pro-Catholic Grant's period of office in Ireland has been largely seen by both nineteenth-century critics and later historians as a failure_Lady Gregory, for example, highlighted his many flaws and attributed his few achievements to his successor Henry Goulburn-it was with Grant's religious evangelical interest in penal reform that a new era of prison inspection was initiated in Ireland. ${ }^{30}$ Archer's piecemeal, forgetful and otherwise unsatisfactory answers must have made for uncomfortable reading in Dublin Castle, and Grant clearly felt that reform was necessary. Before the committee had even reported, he introduced and had passed his first Irish prisons act-a short measure concerning the appointment of clergymen as chaplains. ${ }^{31}$ Another modest bill that followed in the next year was a precursor to a more extensive and ultimately successful effort in the spring and summer of $1821 .{ }^{32}$ In the meantime Grant followed the British lead by abolishing gaol fees in Ireland. ${ }^{33}$

The May 1821 version of Grant's prisons bill noted that 'many bridewells and houses for idiots or lunatics do not appear to have been so visited,' and demanded that Archer as inspector-

\footnotetext{
28 Ibid., pp. 173-95.

29 A Statement of the Objections of the Association for the Improvement of Prisons, and of Prison Discipline in Ireland (Dublin, 1819), p. 9. Grant remained paton until at least 1824. See Fifth Report of the Association for the Improvement of Prisons, and of Prison Discipline in Ireland (Dublin, 1824), p. 3.

${ }^{30}$ Lady Augusta Gregory (ed.), Mr Gregory's Letter-Box, 1813-30 (London, 1898), pp. 116-17, 128-29, 210-

11. Brian Jenkins, Era of Emancipation: British Government of Ireland, 1812-1830 (Kingston and Montreal, 1988), pp. 138-54, 161-62; Martin, 'Charles Grant,' p. 293; Beaumont, 'Charles Grant,' p. 196.

31 Prisons (Ireland) Act, 1819 (59 Geo. III. c. 100).

32 Journal of the House of Commons, 75 (25 May 1820), p. 238; A Bill to Amend an Act... Relating to Prisons in Ireland, H.C. 1821 (493), iii; Prisons (Ireland) Act, 1821 (1 \& 2 Geo. IV. c. 57).

33 Abolition of Gaol Fees (Ireland) Act, 1821 (1 \& 2 Geo. IV. c. 77).
} 
general provide a full list of every prison, large and small, in the country. ${ }^{34}$ At the same time Grant listened attentively to the advice of the Irish SIPPD, expressing his hope to one of its officers that he might "perhaps be able to fulfil the wish of the society, $\&$ shall on every account have pleasure in so doing'. While the SIPPD was keen to include provisions for educating and employing prisoners, Grant asked its leaders to return quickly with their views on a much broader range of prison issues. ${ }^{35}$ With the SIPPD's assistance, then, what Grant had originally described as 'a very short bill' grew into a much more substantive measure. One of the key changes was the wording of the section that set out the role of government inspectors. Because the work of visiting every prison was deemed 'too extensive and arduous for the performance of one officer,' the act permitted the appointment of two 'inspectors-general of prisons,' who were to divide up the country between them and visit every prison at least biennially. Their detailed reports were to be sent to grand juries at each assizes, and every year a national report was to be prepared for Dublin Castle that would be laid before parliament. Heavy penalties were established for inspectors who failed to carry out their duties, and their salaries were to be paid only after their annual reports had been received. ${ }^{36}$ In carrying this prison bill through parliament, Grant established a distinctly modern model of prison inspection, based on clear responsibilities and penalties. ('Modern' was a word that one of the new inspectors himself later used to describe the system). ${ }^{37}$ By also requiring the new inspectors to compile a list of all the smaller prisons, the act hinted that further powers could soon be granted to manage, or even close, notorious local centres of confinement. This possibility soon became reality. By extending the powers of the government inspectors, and by threatening embarrassment to local elites through detailed and elegantly-composed reports to be laid before parliament, the authors of the

\footnotetext{
34 A Bill to Amend an Act... Relating to Prisons, p. 4.

35 Charles Grant to Charles Fox, 6 June 1820 (CSORP 1820/552, NAI).

36 Prisons (Ireland) Act, 1821 (1 \& 2 Geo. IV. c. 57), ss. 8-15.

${ }^{37}$ James Palmer, A Treatise on the Modern System of Government Gaols, Penitentiaries, and Houses of Correction, with a View to Moral Improvement and Reformation of Character; also a Detail of the Duties of Each Department of a Prison, together with Some Observations on the State of Prison Discipline, at Home and Abroad, and on the Management of Lunatic Asylums (Dublin, 1832), p. 91.
} 
new law shifted the ethos of Irish prison inspection from a voluntary to a programmatic code. A clear signal of the dawning new future appeared when Archer's son Robert failed to succeed his father upon the latter's retirement in late 1821. Dublin Castle officials quickly made clear that Robert Archer would not be recommended, and that Grant had already decided to bring in new blood in order to carve out and consolidate the new powers of central government. 'I could not recommend you,' William Gregory informed Archer, adding that there were other candidates 'better qualified for the situation'. ${ }^{38}$

Historians of nineteenth-century Ireland have often highlighted the exceptionalism of certain aspects of Irish government within the United Kingdom. Whether in policing, education, or public works, government interventions were in Roy Foster's words 'more decisive and more extensive' than in mainland Britain and tended to develop into what Gearóid Ó Tuathaigh and others have termed a 'highly-centralised' form of administration. ${ }^{39}$ In the words of Oliver MacDonagh, the management of Ireland's prisons closely followed this 'familiar pattern of early centralisation and nationalisation,' where 'state power and responsibility steadily advanced, stages ahead of Britain, and of the majority of European countries'. ${ }^{40}$

In England, Wales, and Scotland there was no comparable system of inspection in the early 1820s. Throughout the preceding decade much of parliament's energy had been spent investigating the deplorable condition of the London prisons, with no fewer than three separate House of Commons inquiries. ${ }^{41}$ Some light was shone on the provincial prisons in an 1819

\footnotetext{
38 William Gregory to Robert Archer, 25 Nov. 1821 (CSORP/SC 1821/53, NAI).

${ }^{39}$ Roy F. Foster, Modern Ireland. 1600-1972 (London, 1988), p. 290; Gearóid Ó Tuathaigh, Ireland before the Famine 1798-1848 (Dublin, 1990), p. 95. See also Oliver MacDonagh, Ireland: The Union and Its Aftermath (London, 1977), Chap. 2; Donald H. Akenson, The Irish Education Experiment: The National System of Education in the Nineteenth Century (London, 1970), pp. 1-16, 376-91.

40 Oliver MacDonagh, 'Ideas and Institutions, 1830-45,' in Vaughan (ed.), New History of Ireland, 5 (part 1), pp. 193-217, esp. pp. 211-12.

${ }^{41}$ Report from the Committee on the State of the Gaols of the City of London, etc., H.C. 1813-14 (157), iv; A Bill for the Better Regulation of the Prisons or Gaols within the Jurisdiction of the City of London, H.C. 1813-14 (263), ii; Report from the Committee on the King's Bench, Fleet, and Marshalsea Prisons, etc., H.C. 1814-15 (152), iv; Journal of
} 
investigation, and in the following year new prison legislation was introduced for England and Wales. The issue of inspection first appeared in a bill of July 1820 to regulate English prisons. Though it failed to pass its first reading in the Commons, the bill proposed that 'visiting justices' should be appointed to regularly inspect prisons and report to magistrates at county quartersessions. These local inspectors had little in common with their more powerful governmentappointed colleagues in Ireland: they were to be selected from county Justices of the Peace, would report to their peers, and would have no powers of enforcement. ${ }^{42}$ In the following session, as Grant's bill for Irish prisons was also passing through parliament, substantial and significant revisions were made to this rudimentary provision for inspection, with a clause added requiring that each prison-keeper forward a brief annual report to the secretary of state detailing the degree of classification of the different kinds of prisoners, showing the greatest number of prisoners held during the year, and indicating whether any alterations had been made to the prison buildings. ${ }^{43}$ Following a debate in a select committee (led by key reformers such as the Tory George Holford and prominent Irish Whig members such as Thomas Spring Rice and Sir John Newport), the bill was further revised so that, in addition to the gaol keeper's annual report (also expanded to some thirty-three questions), the 'visiting justices' were also required to send reports every three months, and the quarter-sessions chairman was directed to forward to the proper authorities the rules and the architectural plans for each prison. ${ }^{44}$ The English reformers, in what materialized in Peel's Prisons Act of 1823, envisaged a system of voluntary local inspection much less onerous than its centrally-structured Irish counterpart, but Holford, in his Thoughts on the Criminal Prisons of This Country (1821), argued that more powers for central

the House of Commons, 73 (5 Feb. 1818), p. 26. Report from the Committee on the Prisons within the City of London and Borough of Southwark, etc., H.C. 1818 (275), viii. An exception was the 1819 Act for the Building of Gaols in Scotland (59 Geo. III. c. 61), that encouraged the rebuilding of gaols in the Scottish royal burghs.

42 Bill for Consolidating into One Act, and Amending, the Laws Relating to the Building, Repairing, and Regulating of Gaols...in...England, H.C. 1820 (313), i, pp. 5, 19.

43 A Bill for Consolidating into One Act, and Amending, the Laws Relating to the Building, Repairing and Regulating of Gaols...in...England, H.C. 1821 (173), i, pp. 25 and Schedule B.

44 A Bill for Consolidating into One Act, and Amending, the Laws Relating to the Building, Repairing and Regulating of Gaols...in...England, H.C. 1821 (701), i, pp. 26, 33 and Schedule B. 
government would be desirable, implicitly taking in account what was bring proposed simultaneously for Ireland:

I have also long been convinced, that very great improvement in the state of the English prisons would result from the appointment of a general inspector, (or more than one, if one should be insufficient) who should personally examine the places, in which prisoners are confined, in different parts of the country, and should make written reports concerning them, from time to time, to the secretary of state.

He claimed that central government had a duty to improve even those prisons that operated at some remove from its authority:

It is fit that government should be regularly informed of the state of its prisons ... and that it should be considered as responsible for the due execution of the laws upon those subjects. If it be asked, in what manner government could interfere for the correction of abuses, the answer seems to me to be obvious; in the first instance, by advice or admonition on the part of the secretary of state ... I know there are those who think that the public is the best inspector, and that the visits of persons whose curiosity or humanity may lead them into gaols, are to do every thing: I do not undervalue the benefits which have arisen, and which will, I hope, still continue to be derived from the inspection of prisons by those who take an interest in that subject, but the greater part of this inspection is given to those gaols where it is least wanted ... especially [those] situated in a remote part of the country. [The observations] of an official inspector, on the contrary, if deemed worthy of attention by the secretary of state, would be communicated by him directly to the chairman of the quarter sessions ... in which case the evil complained of would be redressed speedily, and without being made matter of public discussion. ${ }^{45}$

${ }^{45}$ Holford, Thoughts on Criminal Prisons, pp. 22-24. 
Though the Webbs claimed that penal reformers 'would not contemplate,' at this time, 'the appointment of government inspectors to insist on the law being obeyed,' it is clear from this passage that the concept of central inspection, following the Irish example, was being openly debated and considered, even if Holford found himself in a minority on the issue. ${ }^{46}$ The Rev. Sydney Smith, writing in the Edinburgh Review, has often been quoted as being representative of the seemingly incontrovertible opposition to the idea in these years: 'We object to the office of prison inspector,' he said, 'for reasons so very obvious ... The prison inspector would, of course, have a good salary ... It is equally matter of course that he would be taken from among treasury retainers; and that he would never look at a prison. ${ }^{47}$ Yet Smyth's liberal scepticism needs to be qualified by what he wrote for the same journal in the following year. In this passage, unremarked upon by other scholars, Smyth inadvertently recognized the benefits of central inspection, and in particular the role that bad publicity could play in forcing change at a local level. This was indeed the most fundamental power that government inspectors possessed: If any visiting justice dissents from the majority, it should be lawful for him to give a separate report upon the state of the prison ... All such reports ... not exceeding a certain length, should be published in the county papers. The chairman's report to the secretary of state should be published in the same manner. The great panacea is publicity; it is this which secures compliance with wise and just laws, more than all the penalties they contain for their own preservation. ${ }^{48}$

In his analysis of British prison inspection in 1971, Giles Playfair highlighted the importance of the 'great panacea' of publicity, pointing out that 'the inspectors were ... in a position to influence local prison administration, if only through the weapon of publicity. In effect, they set

\footnotetext{
${ }^{46}$ Webb, English Prisons under Local Government, p. 75; Henriques, Before the Welfare State, pp. 250-52; Stockdale, 'A Short History of Prison Inspection,' pp. 213-16.

${ }^{47}$ Sydney Smith, 'Prisons,' for the Edinburgh Review (1821), reprinted in The Works of the Rev. Sydney Smith (Boston, 1854), p. 160. See also Webb, English Prisons under Local Government, p. 75; Stockdale, 'A Short History of Prison Inspection,' p. 214.

${ }^{48}$ Smith, 'Prisons, Works of Rev. Sydney Smith, , p. 166.
} 
themselves up as policy-makers. ${ }^{49}$ If in the 1820 s the idea of central-government inspectors was politically unacceptable in England, it cannot be argued that there was no appreciation of the benefits they could offer in terms of efficiency, uniformity of standards, and enforcement. Despite opposition from English municipal corporations, the essential provisions of the 1821 bill eventually reached the statute book in 1823 , thanks to some assistance from Peel. ${ }^{50}$ In its final form the act applied to both England and Wales, but only to large county gaols (all references to smaller prisons and bridewells were removed by a House of Lords amendment) and to a list of seventeen smaller towns, all in England. ${ }^{51}$ Fundamentally, the measure was an exercise in compromise. Peel hoped that new larger and more efficient county gaols would tempt municipal corporations to close their often primitive 'dungeons' (as they were often described) and agree to share facilities with their neighbours. In this way, he argued, great improvements could be made without central government interfering, inspecting and dictating. ${ }^{52}$ In dealing with the problems of Scotland's numerous small prisons, Peel advocated a similar policy of amalgamation and consolidation. Nevertheless, throughout Britain local rivalries and disputes often meant that little was actually achieved; advances were delayed until the 1830s, when there was more powerful central-government involvement. ${ }^{53}$ The gaol reports as sent to the secretary of state often

\footnotetext{
${ }^{49}$ Giles Playfair, The Punitive Obsession: An Unvarnished History of the English Prison System (London, 1971), pp. $79-80$

${ }^{50}$ For opposition to the bill, see Journal of the House of Commons, 77 (31 May 1822), p. 304 and (11 June 1822), p. 334; A Bill... for Consolidating and Amending the Laws Relating to the Building, Repairing and Regulating of Certain Gaols, Bridewells, and Houses of Correction, in England and Wales, H.C. 1822 (324), ii; Prisons Act, 1823 (4 Geo. IV. c. 64). For Peel's involvement, see Gash, Mr Secretary Peel, p. 315; Simon Devereaux, 'In Place of Death: Transportation, Penal Practices, and the English State, 1770-1830,' in Carolyn Strange (ed.), Qualities of Mercy: Justice, Punishment, and Discretion (Vancouver, 1996), pp. 52-76, esp. p. 64; Follett, Evangelicalism, Penal Theory, and the Politics of Criminal Law Reform, pp. 174-75.

${ }^{51}$ Amendments Made by the Lords to the Bill, Intituled [sic], an Act for Consolidating and Amending the Laws Relating to the Building, Repairing, and Regulating of Certain Gaols, Bridewells, and Houses of Correction, in England and W ales, H.C. 1823 (463), i. The seventeen towns were Bristol, Canterbury, Chester, Coventry, Exeter, Gloucester, Kingstown-upon-Hull, Leicester, Lincoln, Litchfield, Liverpool, Newcastle, Norwich, Nottingham, Portsmouth, Worcester, and York. The House of Lords requested the removal of Bath and Louth (Lincolnshire) from the final list. For other less important prison legislation in this period, see the Advances for Gaols Act, 1823 (4 Geo. IV. c. 63); the Gaol Sessions Act, 1824 (5 Geo. IV. c. 12), and the Gaols (England) Act, 1824 (5 Geo. IV. c. 85).

${ }^{52}$ Hansard 10 (2nd ser.), cols. 241-47, esp. col. 242. Hansard 10 (2nd ser.), col. 1283.

53 Report from the Select Committee on the State of Prisons in Scotland, H.C. 1826 (381), v, pp. 3-4; Hansard 90 (2nd ser.), cols. 45-47. Local opposition derailed attempts at prison reform in Scotland throughout the
} 
provided only minimal detail and tended to claim that local prisons were well built, well managed and not worthy of added investigation. ${ }^{54}$ Furthermore, smaller prisons remained outside the remit of central government, and abuses within them became scandals without easy solution.

In Ireland the situation was very different. The two new inspectors that Grant appointed, who assumed their offices in 1822, were both army men: Major James Palmer and Major Benjamin Blake Woodward. Both had previous experience with managing large public institutions in Dublin that catered for the poor and ill: Palmer was governor of the House of Industry, and Woodward a board member of the Westmorland Lock Hospital. ${ }^{55}$ Soon after they accepted their positions in December 1821, Grant left Ireland and was replaced by Goulburn, who, despite not sharing Grant's sympathies on the Catholic issue, proved equally enthusiastic about centralizing control over Ireland's prisons and about diminishing the power of the county gentry. He encountered little opposition in Ireland. As during Peel's tenure in the preceding decade, Ireland presented opportunities for more expansive government intervention than would have been politically acceptable in Britain. ${ }^{56}$ Grant had called for a full list of every gaol and bridewell in Ireland, and by mid-1822 this work was complete. Thereafter Goulburn introduced another measure that extended the power of central government to shut bridewells deemed unsatisfactory, to set up 'district' bridewells in place of several smaller ones (an exercise in

1820s, with unsuccessful bills in 1828 and 1829, and with a minor success in the 1829 Gaol Reports (Scotland) Act $(10$ Geo. IV. c. 54) that simply extended the reporting measures of the 1823 Prisons Act to Scotland. See A Bill to Amend the Laws Relating to the Building, Enlarging and Repairing Gaols in Scotland, and for Regulating Such Gaols, etc., H.C. 1828 (306), iii.

${ }^{54}$ See for example Copies of All Reports... of Certain Gaols and Houses of Correction, in England and Wales, H.C. 1826-27 (46), xix, pp. 320-23 (Portsmouth).

55 James Palmer to Charles Grant, 18 Oct. 1820 (CSORP 1820/739, NAI); Benjamin Woodward to Charles Grant, 17 July 1820 (CSORP 1820/1391, NAI). See also McDowell, Irish Administration, pp. 15152.

${ }^{56}$ Galen Broeker, Rural Disorder and Police Reform in Ireland 1812-36 (London, 1970), pp. 1-19, 228-39. 
amalgamation), and to ensure that no prison would be built in Ireland before having its plan and estimated costs approved by government. ${ }^{57}$

From 1823 onwards the inspectors forced the closure of many bridewells. They generally warned Irish grand juries one year that their prison was 'illegal' and should be 'abolished,' giving them a chance to improve it, and then the next year, after this had generally failed to happen, they moved to exercise their legal powers. ${ }^{58}$ Of the 136 smaller prisons in Ireland in 1822, 29 were shut over the next decade, and 75 were newly erected or altered to meet the legal requirements for classification—segregation of prisoners by gender, age, and type of crime, by the availability of exercise yards, and so on. ${ }^{59}$ The reform of these smaller prisons was the inspectors' greatest success. By the mid-1820s, with the cooperation of the Cork grand jury, the inspectors had developed in that county what they termed their 'model' system for smaller prisons. This model combined the extensive rebuilding of bridewells (with financial assistance from central government) and a new regime of 'aggressive' inspection (to quote Palmer). The model also entailed the development of a new scheme of management under what were termed boards of superintendence, where Justices of the Peace, clergymen and other members of the local elite took charge of the day-to-day running of bridewells (a system itself modelled on what was then normal in many English counties).$^{60}$ Seven large new bridewells (Fig. 1) and half a dozen smaller ones were built in County Cork permitting the classification system to be introduced; through efficient management and cooperation with the county gaol the cost of

\footnotetext{
57 Prisons (Ireland) Act, 1822 (3 Geo. IV. c. 64), ss. 31, 49.

58 See, for example the reports on the bridewells of Rathcormack and Buttevant in County Cork in Second Report of the Inspectors General on ... the Prisons of Ireland, H.C. 1824 (294), xxii, p. 44; Third Report of the Inspectors General on ... the Prisons of Ireland, H.C. 1825 (493), xxii, p. 43.

59 First Report of the Inspectors General on ... the Prisons of Ireland, H.C. 1823 (342), x, pp. 69-71; Tenth Report of the Inspectors General on ... the Prisons of Ireland, H.C. 1831-32 (152), xxiii, pp. 51-53; Palmer, A Treatise on the Modern System of Government Gaols, pp. 88-90. In 1823 there were 177 prisons in Ireland; 41 were county gaols and 136 were bridewells. By 1832 the total number of prisons had fallen to 147; 40 were county gaols and 107 were bridewells.

60 Third Report of the Inspectors General on ... the Prisons of Ireland, H.C. 1825 (493), xxii, pp. 10-11; Eleventh Report of the Inspectors General on ... the Prisons of Ireland, H.C. 1833 (67), xvii, p. 8; Palmer, A Treatise on the Modern System of Government Gaols, p. 91.
} 
running each of these bridewells fell dramatically. ${ }^{61}$ By 1830 Palmer and Woodward were keen to show other Irish counties the benefits of the Cork system, and with statistics, architectural plans and prose they made an economic as well as a moral argument for penal reform. ${ }^{62}$ The neighbouring counties of Kerry and Limerick soon followed, even appointing the same architect who had worked in Cork, but it took some time and many negative reports from the inspectors for other counties, such as Tipperary, to finally take action. ${ }^{63}$ When the salaries paid to Palmer and Woodward were debated in the Commons in August 1831, George Dawson suggested that as the 'objects for which those gentlemen were appointed had long since been accomplished,' their positions should be abolished. Thomas Spring Rice, speaking as Secretary to the Treasury, replied that it was essential to maintain their employment 'if it were desired to keep [Irish] prison discipline in the good state in which it now was'. ${ }^{64}$

\footnotetext{
${ }^{61}$ By 1834 the cost to cesspayers of the bridewells in Cork and Tipperary was $£ 236$ and $£ 555$ respectively for comparable numbers of bridewells and committals in the two counties. See Thirteenth Report of the Inspectors General on ... the Prisons of Ireland, H.C. 1835 (114), xxxvi, pp. 8, 35, 54.

${ }^{62}$ Eleventh Report of the Inspectors General on ... the Prisons of Ireland, H.C. 1833 (67), xvii, pp. 8, 30, 56-57.

${ }^{63}$ For County Kerry, see Fifth Report of the Inspectors General on ... the Prisons of Ireland, H.C. 1827 (471), xi, p. 51. Southern Reporter, 30 June 1827 and 14 July 1827. For County Limerick, see Seventh Report of the Inspectors General on ... the Prisons of Ireland, H.C. 1829 (10), xiii, p. 59. For County Tipperary, see Eleventh Report of the Inspectors General on ... the Prisons of Ireland, H.C. 1833 (67), xvii, p. 30.

${ }^{64}$ Hansard 6 (3rd ser.), col. 944.
} 


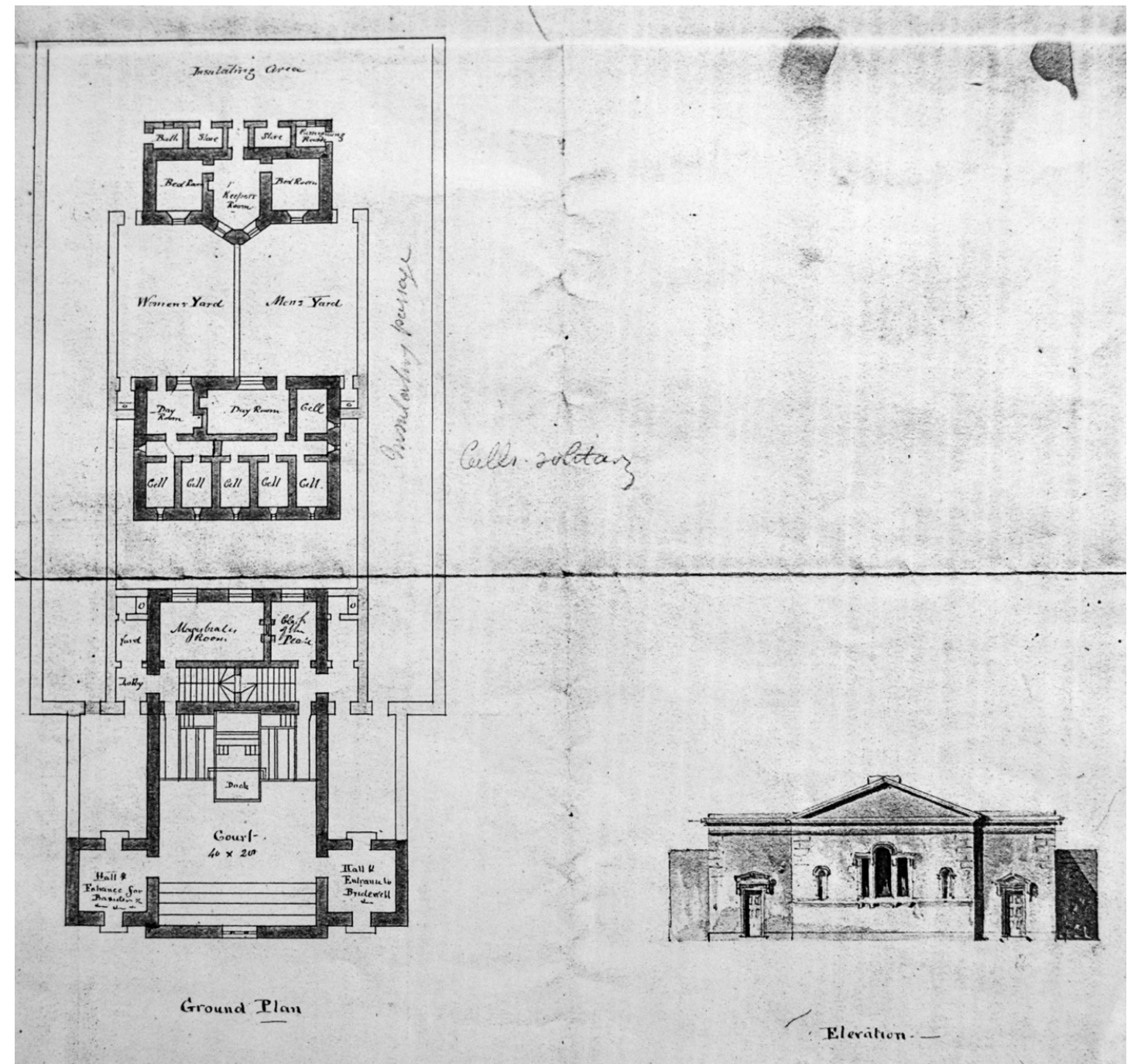

Fig. 1. The standard design for courthouses and bridewells in County Cork (1824), by George Richard Pain, an architect who had trained with John Nash. Efficiently combining a quarter-sessions courthouse and a bridewell, that closely adhered to the post-1822 Irish regulations for classification, exercise yards, perimeter walls and inspection, this design was widely emulated throughout Ireland and was celebrated by the new prison inspectors as an integral part of their 'model' system. Irish Architectural Archive - Lismore Castle Collection.

In 1832 Palmer boasted that over the previous decade in Ireland there had been 'a striking instance of a most important object completely accomplished and worthy of the attention of the authorities in other countries'. He also declared that the new bridewells 'will surpass those of any other country; and why? Because they in Ireland alone form part of a system.' Palmer's hyperbole was not as unbounded as it might appear: conditions had undoubtedly 
improved greatly, notorious prisons had been shut and cooperation with local elites had been established. An inter-county rivalry was set going, with the inspectors playing off neighbouring elites against each other, condemning failures in their parliamentary reports (Palmer later described them as documents of 'public notoriety'), and benefitting from the endorsement of travelling assize judges who passed from county to county and made comparisons based on what they had seen in the towns they visited and on what they had read in the prison reports. ${ }^{65}$ As Sydney Smith had realized in the British context, publicity was a powerful weapon. Concurrently, some Irish counties proposed moving the location of their assizes and building new county gaols. In these cases Palmer and Woodward were consulted by the Irish Privy Council as expert witnesses; in this role they became 'policy-makers' (as Playfair has noted of their post-1835 British counterparts), further fortifying and embedding their influential position in the Irish administration. ${ }^{66}$ Palmer played a key role, for example, in the decision to build a new courthouse and county gaol in Nenagh after Tipperary was split into two ridings in $1836 .{ }^{67}$ Yet Mitchel Roth has recently claimed that in the late 1830s 'Ireland was well behind England in any meaningful prison reform efforts' ${ }^{68}$ This criticism does not stand up to a detailed analysis of the real achievements of the new prison inspectors from 1822 onwards. Though there were clearly still problems — most infamously at Dublin's Newgate gaol—the reality was that the introduction of classification throughout Ireland's main county gaols and in its bridewells was so extensive, and the dedication of the new inspectors so strong in the 1820s and early 1830s, that when the tide turned in favour of the separate system—one cell for one prisoner-in the mid-1830s, Ireland's prison infrastructure was too new to be overhauled once more. ${ }^{69}$ The Irish inspectors could not

\footnotetext{
${ }^{65}$ Palmer, A Treatise on the Modern System of Government Gaols, pp. 90, 92; Eleventh Report of the Inspectors General on ... the Prisons of Ireland, H.C. 1833 (67), xvii, p. 8. For the comments of a travelling assize judge, see 'Carlow Assizes,' Finn's Leinster Journal, 11 April 1827.

${ }^{66}$ For the inspectors' role in the Privy Council cases relating to counties Tipperary and Waterford, see Donal A. Murphy, The Two Tipperarys: The National and Local Politics, Devolution and Self-Determination, of the Unique 1838 Division into Two Ridings, and the Aftermath (Nenagh, 1994), pp. 87-91, 294-97.

${ }^{67}$ Grand Jury (Ireland) Act ,1836 (6 \& 7 Will. IV. c. 116), ss. 176-77.

${ }^{68}$ Mitchel P. Roth, Prisons and Prison Systems: A Global Encyclopedia (Westport, CT., 2006), p. 138.

${ }^{69}$ Thirteenth Report of the Inspectors General on ... the Prisons of Ireland, H.C. 1835 (114), xxxvi, p. 18.
} 
have known that their colleagues in Britain would later commit themselves to this system, which necessarily demanded the large-scale reconstruction of most prisons, or that by doing so, they would make Ireland's relatively new prisons prematurely out-of-date. When Roth criticizes the achievements of prison reformers in Ireland from the standpoint of the late 1830s, he neglects to acknowledge the inspector-led accomplishments of the previous decade, when no comparable advance was being made in Britain.

By the late 1820s Ireland's tightly-managed and centrally-inspected prisons were without doubt more efficient and in many cases more humane than the many small British prisons that still remained outside central-government control. The contrast was even starker with Scotland, which looked more and more like what Ireland would have been had Charles Grant and Henry Goulburn not come to Ireland. 'It is remarkable what little improvement has taken place' in Scotland, Palmer commented. ${ }^{70}$ But how did the Irish achievements filter across to Britain and inform penal-reform debates there? It has already been noted that the Inverness gentry called in 1825 for the introduction throughout Scotland of the central-government model of inspection developed in Ireland. ${ }^{71}$ Later in 1828 a House of Commons select committee, led by Lord John Russell, Peel, and others, investigated the condition of prisons in England and Wales. Samuel Hoare, chairman of the SIPD was questioned by Russell on the issue of central-government inspection with specific reference to Ireland. 'Do you not think,' asked Russell, 'that it would be very expedient to adopt the practice prevalent in Ireland of appointing a general inspector of gaols?' 'Highly expedient,' Hoare replied, 'and the effects in Ireland have been very beneficial; and if the magistracy consented to it here, I have no doubt but that we might have the same beneficial results.' Pressed as to whether more detailed reports sent to the secretary of state would result in a 'uniformity' of prison standards, Hoare was clear that nothing would be as effective as central-government inspection. 'By the appointment of inspectors,' he said, 'the end

\footnotetext{
70 Palmer, A Treatise on the Modern System of Government Gaols, p. 83.

${ }^{71}$ Report from the Select Committee on the State of Prisons in Scotland, H.C. 1826 (381), v, p. 81.
} 
would be attained. ${ }^{72}$ Acknowledging in their conclusions that there were 'many small gaols' where 'the ancient vice and disorder prevail,' the members of the select committee were of two minds about the introduction of inspectors. Although Stockdale has argued that the committee 'rejected [Hoare's] suggestion, ${ }^{73}$ this is not borne out by a more nuanced reading of its actual conclusions, and in particular the clause they added at the end:

It has been suggested that an inspector of prisons, as in Ireland, should be appointed. It is very questionable, however, whether the authority of the county magistrates should in any degree be superseded. Being on the spot, they are, if they give themselves the trouble, better judges of what is required and what is done than any periodical inspector. If, however, an inspector should be appointed, it would perhaps be advisable at first to send him only to the town and borough gaols which have not been united to the county prisons. According to the last report of the Prison Discipline Society, 140 of these gaols still require to be regulated by law. ${ }^{74}$

Four years later, in 1832, another select committee, this time set up by a Whig government, ploughed the same furrow as part of a wider investigation into crime and punishment. Hoare retreated somewhat from his earlier stance, arguing that British prison inspectors 'must not by any means interfere with the jurisdiction of the magistrates,' and when asked what powers they should have, he replies, 'I would give him no authority whatever, but to visit all places of confinement, and to make the report to the magistrates and the Home Office. ${ }^{75}$ This more limited measure_essentially following Grant's Irish act but leaving out Goulburn's later extra powers — was less likely to offend magistrates. Elizabeth Fry added further weight to the Irish precedent in her testimony:

\footnotetext{
72 Report from the Select Committee on Criminal Commitments and Convictions, H.C. 1828 (545), vi, p. 90.

73 Stockdale, 'Short History of Prison Inspection,' p. 214.

${ }^{74}$ Report from the Select Committee on Criminal Commitments and Convictions, p. 16.

75 Report from Select Committee on Secondary Punishments, H.C. 1831-32 (547), vii, pp. 115-16.
} 
I think it is right to say of the state of the prisons in Ireland that they do credit to the magistrates and to the inspectors, general and local. I should say, take the average, I am not sure whether the principal prisons in Ireland are not better conducted than they are in England; the general inspectors, Major Palmer and Major Woodward, inspect the prisons annually, and there are also local inspectors who visit daily. ${ }^{76}$

This select committee broke new ground by being the first to make a clear and unequivocal recommendation that government inspectors should be appointed throughout Britain:

To insure a due observance of the regulations for the government of gaols, and a general uniformity of discipline, your committee recommend that, in addition to the visiting magistrates, inspectors of prisons be appointed; that these officers be required to visit all the prisons in the kingdom, including those under corporate jurisdictions, at least once a year, and report to the secretary of state for the Home Department, who shall annually lay such reports before parliament. ${ }^{77}$

It is not known if Palmer's book, A Treatise on the Modern System of Government Gaols, Penitentiaries, and Houses of Correction...with Some Observations on the State of Prison Discipline at Home and Abroad (Dublin, 1832), was available to the members of the committee, but it is clear that he was keen to publicize his achievements in Ireland to a wider (and presumably British) audience. Dedicating his book to 'the lord lieutenants and magistrates of Great Britain,' Palmer observed that 'the present state of things falls short of rendering the English prisons places of rational punishment and reform'. He detailed the reforms that had been implemented in Ireland, and after an impressive sweeping review of penal reform stretching from Russia to Sweden, and from

\footnotetext{
${ }^{76}$ Ibid., p. 127.

77 Ibid., pp. 7-8.
} 
Quebec to Jamaica, he concluded by expressing the wish that 'Great Britain will be as eminent in her jurisprudence and the moral government of her prisons as she is in the arts and sciences, commerce and manufactures'. ${ }^{78}$

Palmer found a supporter in the House of Lords in 1834, when Lord Wharncliffe drew attention to the Irish system of inspection. 'It would,' he said, 'be a good thing to adopt a similar plan in this country.' Lord Melbourne, the Home Secretary, agreed and stated that it was government policy to make the necessary changes. ${ }^{79}$ While this was clearly a notable shift in policy from the preceding decade, the measure that the Whig government proposed to introduce was, as previously noted, the same one that had received some support as far back as 1821 , a nd that had been backed by many individuals and select committees in the intervening years. Most important, by 1834 the success of the Irish system was evident for all to see, and the Irish inspectors were keen to publicize their work to a wider audience. When the British Prisons Act finally became law in 1835 , it was preceded by another exhaustive parliamentary committee, led in the Lords by the Duke of Richmond, which teased out the issues one more time.

While the recent introduction of new government inspectorates in Britain such as the factory and poor-law inspectors had normalized the concept of prison inspectors by the mid1830s, it has been noted that these complementary systems of enforcement-by-inspection were rarely if ever discussed together. During the 1835 House of Lords inquiry, only Sir Frederick Adair Roe (a London magistrate) mentioned factory inspectors. When asked, 'From what class of persons would you select the [prison] inspectors?' he replied, 'They must be of a high class of persons ... I should say that they should be men of the same class as the factory commissioners. ${ }^{80}$ In every other case it was to Ireland that the 1835 gaols committee looked, and

\footnotetext{
${ }^{78}$ Palmer, $A$ Treatise on the Modern System of Government Gaols, pp. vi, 81-99.

${ }^{79}$ Hansard 24 (3rd ser.), cols. 604-32.

${ }^{80}$ First Report from the Select Committee of the House of Lords Appointed to Inquire into the Present State of the Several Gaols and Houses of Correction in England and Wales, H.L. 1835 (438), xi, p. 252. When the assistant poor-law commissioners (later known as inspectors) were discussed in this report, it was not in relation to the inspection in prisons. See ibid., p. 71; Fourth and Fifth Reports...on...gaols etc., H.L. 1835 (441), xii, p. 502.
} 
Samuel Hoare, William Seymour, Baron Carbery and Elizabeth Fry all cited the Irish situation when asked about penal reform. ${ }^{81}$ Fry said:

I think nothing hardly is so likely to do good ... The government inspectors I consider as officers of the greatest importance, and that they do great good in Ireland, and that they would do much good in England. ${ }^{82}$

Lord Carbery, a Cork landlord and magistrate, had been involved in setting up the Cork model bridewell system in the 1820s, and naturally he drew favourable attention to it in his testimony, as well as to the work of the Irish inspectors. ${ }^{83}$ William Seymour, a Brighton magistrate, observed that he had 'read attentively for several years all the reports of the prisons in Ireland, and the effect produced by inspectors there convinces me that they will be of the greatest consequence. ${ }^{84}$ Hoare was still reluctant to grant the new British inspectors powers that might conflict with those of resident magistrates, but when asked about the Irish inspectors, he produced a reassuring letter which he had received from them:

They had heard of this committee and felt extremely interested in the success of its endeavours, and they wrote me an account of what they considered inspectors ought to do. They state, "The office in Ireland is, as it should be, limited in power; the province of the inspectors general is, by their personal exertions, to aid the local authorities of counties ...; in short, to watch over the whole system of prison discipline. Such an office, without interfering with the local authorities, is a necessary aid to them and in point of fact is constantly referred to in all doubtful cases. ${ }^{85}$

\footnotetext{
${ }^{81}$ An exception was William Crawford, who discussed inspection with reference to his knowledge of American prisons. See First Report...on ...gaols etc., H.L. 1835 (438), xi, pp. 11-12.

82 Second Report...on... Gaols etc., H.L. 1835 (439), xi, p. 341. In his article 'Jeremy Bentham, Elizabeth Fry, and English Prison Reform,' pp. 681-90, Cooper downplays the significance of Fry's testimony at this inquiry.

${ }^{83}$ First Report...on ... Gaols etc., H.L. 1835 (438), xi, pp. 292-93.

${ }^{84}$ Ibid., p. 177.

${ }^{85}$ Ibid., pp. 15-16.
} 
The inquiry was little more than a rubber-stamping exercise for government policy that had already been decided. ${ }^{86}$ Only Sir Peter Laurie, a Middlesex magistrate, objected in principle to the appointment of inspectors in Britain; he advanced the standard arch-Tory argument that it would interfere with the power of magistrates. In spite of Richmond's best efforts to convince him otherwise, Laurie stuck to his view that the inspectors would be 'a political appointment; and it would give great power to the secretary of state, much greater, in my opinion, than ought to be vested in him. ${ }^{87}$ In the bill that followed that summer, the Whig government proposed that five inspectors be appointed in England and Wales, and two in Scotland ${ }^{88}$ In the final act some revisions were made, with the result that five inspectors instead of seven were to take charge of the entirety of Great Britain. A clause was also added that established penalties for deliberately obstructing the work of the new inspectors; predictably, this clause followed closely the wording of a similar provision in an earlier Irish law. ${ }^{89}$

The introduction of government inspectors for British prisons in 1835 was not a panacea for every penal-reform issue. The first inspector appointed for Scotland was Frederic Hill, who later recalled that John Russell had said on meeting him: 'Mr Hill, I have chosen Scotland as your chief district because there is most work to be done there. ${ }^{90}$ In terms of penal reform Scotland was easily the most backward part of the United Kingdom, and Hill's task was formidable. He faced much opposition in his earliest years, but by the late 1830s the process of centralization

\footnotetext{
${ }^{86}$ Webb, English Prisons under Local Government, p. 111. The London-based SIPD was also convinced of the benefits of inspection and called for the introduction of such a measure in its March 1835 submission to the House of Lords inquiry. See Fourth and Fifth Reports...on...Gaols etc., H.L. 1835 (441), xii, p. 396. Further support can be found in 'A County Magistrate', A Letter to His Grace the Duke of Richmond, K.G. Chairman of the Committee of the House of Lords, Appointed to Inquire into the State of the Prisons of the United Kingdom (London, 1835), p. 30.

${ }^{87}$ Fourth and Fifth Reports...on...Gaols etc., H.L. 1835 (441), xii, pp. 461-64.

88 A Bill...for Effecting Greater Uniformity of Practice in the Government of the Several Prisons in England and Wales; and for Appointing Inspectors of Prisons in Great Britain, H.C. 1835 (403), iv, p. 3.

${ }^{99}$ Prisons Act, 1835 (5 \& 6 Will. IV. c. 38), ss. 7, 8. For the preceding Irish act, see Prisons (Ireland) Act, 1826 (7 Geo. IV. c. 74), s. 61.

${ }^{90}$ Frederic Hill, An Autobiography of Fifty Years in Times of Reform, ed. Constance Hill (London, 1894), p. 115.
} 
and consolidation advocated by Peel in the early 1820s was finally happening, and a series of large new prisons were built on the separate system. As David Smith has suggested, the eventual reformation of the Scottish prisons on the separate penitentiary system in the 1840s became in turn the model for England in the 1860s, just as I have argued that Ireland served as the model for inspection in England thirty years previously. ${ }^{91}$ In England and Wales the new inspectors were able to report more adeptly on failings in prisons, especially in the smaller ones that had remained outside earlier legislation, and their reports gave central government a new wealth of information, leading, as James Willis has argued, to full central-government ownership, management, and control of prisons. ${ }^{92}$

Yet the effectiveness of the new inspectors should not be overstated, as Tomlinson has pointed out, 'The local authorities' autocracy was scarcely destroyed ... Criticisms were made that the visits of inspectors ... were infrequent and superficial. As for the local authorities being obliged to introduce changes, the difficulty was to persuade them to introduce changes, as the sanctions necessary for enforcement were manifestly lacking. ${ }^{93}$ Tomlinson later acknowledges, however, that after the first decade of central inspection the 'worst and most colourful abuses' of prison discipline had been rectified, just as Palmer and Woodward had drawn attention to the remarkable achievements of their first ten years. ${ }^{94}$ Perhaps the most telling endorsement of the central inspection system came with its emulation in other countries after 1835. Lord Macaulay led a prison-reform committee that considered India's prisons in 1836-38, and following its recommendation that inspectors should be appointed, the first officer took up his post in the

\footnotetext{
${ }^{91}$ David F. Smith, 'Scottish Prisons under the General Board of Directors, 1840-1861,' Albion: A Quarterly Journal Concerned with British Studies 15:4 (Winter, 1983), pp. 287-312, esp. pp. 309-10.

${ }^{92}$ James J. Willis, 'Transportation versus Imprisonment in Eighteenth- and Nineteenth-Century Britain: Penal Power, Liberty, and the State,' Law \& Society Review 39:1 (March 2005), pp. 171-210, esp. pp. 19091. See also Hinde, British Penal System, p. 110.

${ }^{93}$ Tomlinson, 'Victorian Prisons,' pp. 55-56.

${ }^{94}$ Ibid., p. 257. Palmer was himself briefly imprisoned as a debtor in the early 1830s, but this seemingly did not much interrupt his work as an inspector. See Returns of Reports... on Complaints Forwarded to the Irish Government... Convict Service in Ireland, H.C. 1843 (547), xlii, pp. 41, 53, 74.
} 
North-West Province in 1844. In France prison inspectors were appointed for the first time in $1838 .{ }^{95}$

British prison reform needs to be understood as a transnational issue and especially an Anglo-Irish concern. As was apparent to reformers of the time, the nations of the British Isles naturally became models for mutual experiment and advance. While in the 1820 s the Inverness gentry were keen to emulate what they knew was happening across the Irish Sea, by the 1860s the tables had turned and Ireland borrowed heavily from the Scottish General Board of Directors. ${ }^{96}$ Undoubtedly, it was the economic backwardness and political instability of Ireland that made it ripe for the first installation of modern central-government inspection, as planned by Charles Grant in 1821. Yet this was the same system that informed and shaped political debate concerning inspection throughout the rest of the United Kingdom, and that led to its eventual emulation. How then do we frame the established understanding of 'Irish exceptionalism' in the pre-famine period, when the example of penal reform constitutes an unusually and perhaps uniquely positive example of government reform in a period marked by strife and poverty? In the cases of other large-scale interventions by central government, their implementation was necessitated by unique religious and economic challenges, and hardly presented a positive model for the rest of the United Kingdom to follow. The possibility of adopting such interventions in Britain could easily be dismissed as unsuitable on account of the exceptionalism of Irish problems: Irish exceptionalism, in short, was rarely if ever seen in a positive or constructive manner. Yet in the case of prison reform the measures introduced in Ireland quickly (within little more than a decade) became standard throughout the rest of the United Kingdom and were lauded by British campaigners. The significant Irish dimension to the British Prisons Act of 1835 has not been given the recognition it deserves.

\footnotetext{
${ }^{95}$ F.A. Barker, The Modern Prison System of India (London, 1944), p. xii; Amarendra Mohanty and Narayan Hazary, Indian Prison System (New Delhi, 1990), pp. 24-25; Patricia O'Brien, The Promise of Punishment: Prisons in Nineteenth-Century France (Princeton, 1982), p. 218. Belgium had employed a prison inspector at least since independence in 1830. See Roth, Prisons and Prison Systems, p. 87.

${ }^{96}$ McDowell, Irish Administration, pp. 155-60.
} 
Furthermore, the role played by the liberal Tory Irish chief secretaries Charles Grant and Henry Goulburn in developing this model of central-government prison inspection that so greatly influenced British policy in subsequent years brings into question the claimes that the new prison inspectors, like their new factory and poor-law counterparts, were landmark achievements of the reforming Whig governments of the 1830s. While influential Whigs such as Lord Richmond facilitated the adoption of the centralized prison-inspection system in the key 1835 act, its origins lay in the preceding decade, not only in the reality and accumulating associated paperwork of the Irish example, but subsequently in the voices of such reformers as Fry, Holford, and others. There was in addition some local support for the concept-from the Inverness gentry for example — long before it was eventually converted into law. With the issue of prison inspection considered as separate and distinct from the other new Whig inspectorates of the 1830s, less emphasis should be put on the supposed great break in British politics following the collapse of the Tory government under Wellington and Peel in 1830, as current histories of British penal reform stress. Instead the continuities in policy between the two decades and the two administrations should be emphasized. This is not to contradict McConville's argument that 'by the mid-1830s the Whig reforms had significantly redefined the relationship between central and local government,' which in terms of the poor law they certainly had, but rather to stress that the new prison policy was already fully in force in one part of the United Kingdom - Ireland — for a decade by the mid-1830s, and that it had been brought into practise, perhaps surprisingly, by a Tory government. ${ }^{97}$ By stressing the continuities between the governments of the 1820s and 1830s, we gain new insights into the ways in which British central government and its relations to the localities grew and developed in the early nineteenth century.

Word count: 11,542 words.

${ }^{97}$ McConville, English Prison Administration, p. 170. 